\section{Fusion machines 'breach treaty and open weapons risk'}

[WASHINGTON] Both the National Ignition Facility (NIF), now under construction at the Lawrence Livermore National Laboratory in California, and the Laser Megajoule project planned near Bordeaux, France, will violate the Comprehensive Test Ban Treaty (CTBT) and could open the way for the development of new, 'pure fusion' nuclear weapons, according to a study published this week.

The Institute for Energy and Environmental Research (IEER), a technically respected group based in Takoma Park, Maryland, calls on parties to the CTBT to issue a ruling on the treaty status of inertial confinement fusion research, which would be conducted at the two facilities. The IEER, which is consistently critical of US nuclear weapons policy, wants both projects halted.

The IEER's report, Dangerous Thermonuclear Quest, says that an operational NIF will lead to strong political demand for so-called 'pure fusion' weapons (see Nature 387,$439 ;$ 1997). These would yield fusion explosions without any need for the fission explosions that trigger fusion in existing thermonuclear weapons.

Both NIF and the Laser Megajoule will generate tiny thermonuclear explosions of a few kilogrammes TNT equivalent, triggered by massive and immobile banks of laser beams. "NIF will not, by itself, lead to pure fusion weapons," says Arjun Makhijani, a plasma physicist who heads the IEER. "But it could play a crucial role by enabling the design of targets for other driven systems, which could be miniaturized."

Makhijani also argues that NIF will create political pressure for the development of pure fusion weapons. "We must prevent the scientific feasibility of these weapons being established, because once it is, the pressure to build them will become irresistible," he says.

David Crandall, director of the NIF office at the Department of Energy, says his department's non-proliferation office and the 'Jasons', a group of scientists who advise the government on complex issues, have confirmed that the machine poses no proliferation risk. Crandall says the signatories to the CTBT accept the definition of a nuclear explosion contained in the earlier Non-Proliferation Treaty (NPT). The NPT specifically permits inertial confinement fusion research.

Makhijani says the CTBT bans all nuclear explosions. "If they wanted a specific exemption for this, they should have asked for it."

The NIF has been under construction for twelve months, has strong Congressional support, and, as Crandall confirms, there is no chance of it being halted in response to the report.

Colin Macilwain

\title{
Plant scientists want foc us on the best and brightest
}

[WASHINGTON] Scott Poethig, a geneticist at the University of Pennsylvania, Philadelphia, who studies the genes controlling the switch from juvenile to adult development in plants, doesn't need to do an in-depth analysis of research statistics to figure out that his branch of science is getting a raw deal from the federal government.

As a grantee of the United States Department of Agriculture (USDA), Poethig's current grant is worth $\$ 66,000$ and lasts for just twelve months. Poethig's wife, Maja Bucan, a behavioural geneticist at the same university, works with mice instead of plants. She is funded by the National Institutes of Health (NIH), where the typical grant, according to agency officials, provides $\$ 240,000$ a year and lasts for four years.

Last week, Poethig took his case to the august halls of the USDA in Washington. At a meeting on 9 July, called by the department to solicit advice on how it should manage a planned new research initiative, he told top science officials at the department to find the best basic research, and support it to the hilt.

"My suggestion is simple," he said. "Make the USDA more like NIH. Fund the best research, not just research on economically useful plants." The brightest scientists are working to understand the basic nature of biological systems, Poethig says; the USDA would best serve US agriculture by supporting them.

Poethig reflects the views of many plant scientists at US universities. Interest in their field is poised to explode: in two weeks' time, for example, private benefactors will announce that they have raised $\$ 150$ million to build a new plant-science institute in St Louis, Missouri (see box). But according to US government figures, support for research and development at the USDA, the main federal sponsor of plant science, slipped from

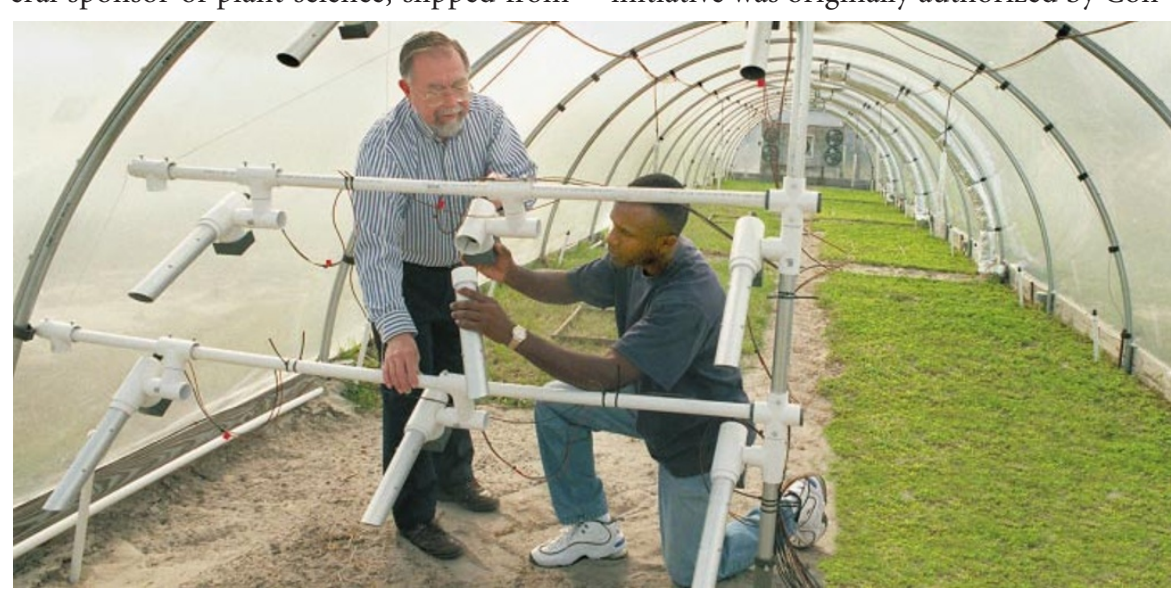

Stunted growth? University agricultural researchers, such as these at the University of Florida studying the effects of rising $\mathrm{CO}_{2}$ on crops, can feel badly treated compared to their colleagues.
$\$ 1.3$ billion in 1992 to $\$ 1.2$ billion last year. USDA support for basic research also fell.

The problem runs deeper than simple resources. Despite a wide consensus in the United States that peer-reviewed, extramuralgrants are the most efficient way to support good science, less than 10 per cent of USDA research money goes on such grants. For at least two decades, various agricultural constituencies, allied with key members of Congress, have fought to resist change that they believe would shift resources from local research stations and agriculture schools to research universities. "I find this very painful," says Lou Sherman, head of the biology department at Purdue University, Indiana. "It has forced one area of science to be less good than it could have been."

When the USDA started funding competitive grants under the so-called National Research Inititiative (NRI), Congress specified that these grants could allow universities to receive overhead payments of only 14 per cent of the value of the grant, compared with payments of as much as 50 per cent on grants from other government agencies.

Sherman calls this a "poison pill", which dissuades universities from chasing the money. University administrators, he says, conclude that agricultural research is not a good area to pursue; they then hire fewer plant and soil scientists. "Congress has hurt agricultural research by making it feel like a poor relation," says Sherman.

Even the chief scientist at the USDA, Michael Roberts, who also holds a position at the University of Missouri, concurs with these complaints. "If we're not careful, the NRI is going to be marginalized," he says, because its grants are too small to sustain researchers for long. Typical NRI grants are worth $\$ 100,000$ and last for two years. The initiative was originally authorized by Con- 
gress in 1990 as a \$500-million-a-year programme, but annual funding for it has never exceeded $\$ 100$ million.

Advocates of agriculture research in Congress, such as Senator Richard Lugar (Republican, Indiana), chairman of the

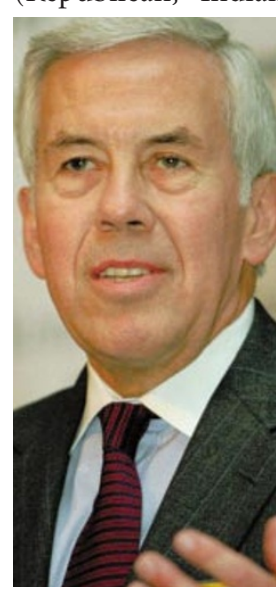

Lugar: seeks to raise research spending.

Senate Agriculture Committee, are well aware of this shortfall. The new programme discussed at last week's meeting, the Initiative for Future Agriculture and Food Systems, results from a bill proposed by Lugar and signed into law by President Bill Clinton on 23 June. The bill would use mandatory funds, previously used in the food stamp programme, to support $\$ 600$ million of new agricultural research over five years.

But the proposal is already in trouble on Capitol Hill. The House Appropriations Committee, in a bill marked up only days after Clinton signed the legislation, expressly blocks the $\$ 120$ million allocated for the measure in the next financial year. The Senate appropriators allowed the spending, leaving the fate of the initiative to be determined in September, when the two chambers reconcile their budget proposals.

Even if the money is forthcoming, some fear that it will be spread too thinly across the activities - research, extension and education - it is supposed to support. Although the legislation specifies some priorities for grants, including genomics, biotechnology and food safety, a dizzying array of research interests feel entitled to a share of the pot.

As speakers at the 9 July meeting made clear, everyone wants a piece of the action, from international economists and organic farmers to environmentalists and soil scientists. The last group's advocate, Karl Glasener, at least introduced some humour: "In short, soil scientists would like everyone to stop treating soil like dirt," he says.

"The thing I worry about most is that it'll be divided up between every interest group, so that nothing that great will come out of it," says Kelly Eversole, a lobbyist for the American Corngrowers' Association, which, along with other growers' groups, wants money to go to large collaborations in areas, such as genomics, that will raise agricultural yields. "We want large, multi-institutional, wellorganized projects," says Lyle Roberts of the American Soybean Association.

Eileen Kennedy, deputy under-secretary for research at the USDA and the agency's senior science official, says the department has introduced more competition into its

\section{Monsanto backs $\$ 150 \mathrm{~m}$ plant science centre}

[WASHINGTON] The US life sciences company Monsanto is linking up with a charitable trust to create an independent \$150 million plant science institute in St Louis, Missouri, that is intended to become an international centre of excellence for interdisciplinary plant research.

Plans for the new centre, strategically placed at the heart of America's agricultural mid-west, are due to be announced on 31 July by former president Jimmy Carter. It will operate as a joint venture between the Missouri Botanical Garden, Washington University in St Louis, the University of Missouri at Columbia, and Monsanto.

Although Monsanto will contribute cash, land and tax credits worth over $\$ 80$ million, it says that it will not lay any claim to intellectual property generated at the institute, which is expected to attract research support from government, industry and private foundations.

A search committee to find a director for the institute by the end of the summer is being chaired by Peter Raven, director of the Missouri Botanical Garden. "We're talking to some of the best plant scientists in the world," says Sam Fiorello, an assistant to the president of Monsanto.

"This is an opportunity to develop for our region a

intramural research programmes, and is considering larger grants, of $\$ 250,000$ or more, for university researchers. Kennedy says that politicians' reluctance to support agricultural research reflects the public's belief that, with food so cheap in the stores, the sector's problems have been solved.

She thinks that "groups that have traditionally been locking horns" - farmers, agribusiness interests and universities - are united behind the initiative. "I don't sense any opposition to agricultural research" in Congress, she says. "It is just that they have a smaller pot of money than they'd like."

No one can predict how much of the $\$ 120$ corporation, but has said that the life sciences operation of the combined group will be based at St Louis.

Each of the four partners will have one representative on the institute's governing board, which will be chaired by William Danforth, chair of the board of trustees at Washington University. William is the brother of John Danforth, the former Missouri senator and chair of the Danforth Foundation. Roy Vagelos, the former chief executive of Merck, is the first of two outside directors who will join the board.

Raven, William Danforth and Virginia Weldon, a recently retired Monsanto executive, dreamed up the idea for the centre on their way to a National Research Council meeting at Irvine, California, in February last year. "I had a vision that this region should be strong in plant biology," says Danforth, adding that the new centre will be "embedded in a community that has a lot going on" in the discipline.

Raven says the great gains in agricultural productivity of the past 50 years have often been made at the expense of the planet's productive capacity, and that the new institute will help to establish ways of raising productivity while preserving topsoil and biodiversity. "We've got to learn to live off the interest, not the principle," he says.

C. M. million will be delivered when the dust settles on the USDA budget in the autumn. If any money does appear, Kennedy will issue an immediate request for proposals, and awards will be made early in the new year.

Senator Lugar's initiative will not enable a fully fledged revival of agricultural science in the United States, and agriculture schools will not soon match the opulence of many academic health centres. But, together with the National Science Foundation's plantgenome initiative (see Nature 390, 539; 1997) and growing private investment, it may herald a modest revival in an undervalued branch of US science.

ColinMacilwain 